\title{
MASTER
}

BDX-613-2416

\section{Thumb Tack Physical Model Evaluation of Polystyrene Bead Foam as an Encapsulant for Electronic Packages}

\author{
By D. J. Fossey \\ and G. D. Swanson
}

Published March 1980

Topical Report

Prepared for the United States Department of Energy Under Contract Number DE-ACO4-76-DP00613.

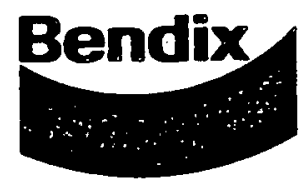

Kansas City

Division 


\section{DISCLAIMER}

This report was prepared as an account of work sponsored by an agency of the United States Government. Neither the United States Government nor any agency Thereof, nor any of their employees, makes any warranty, express or implied, or assumes any legal liability or responsibility for the accuracy, completeness, or usefulness of any information, apparatus, product, or process disclosed, or represents that its use would not infringe privately owned rights. Reference herein to any specific commercial product, process, or service by trade name, trademark, manufacturer, or otherwise does not necessarily constitute or imply its endorsement, recommendation, or favoring by the United States Government or any agency thereof. The views and opinions of authors expressed herein do not necessarily state or reflect those of the United States Government or any agency thereof. 


\section{DISCLAIMER}

Portions of this document may be illegible in electronic image products. Images are produced from the best available original document. 
This report was prepared as an account of work sponsored by the United States Government. Neither the United States nor the United States Department of Energy, nor any of their employees, nor any of their contractors, subcontractors, or their employees, makes any warranty, express or implied, or assumes any legal liability or responsibility for the accuracy, completeness or usefulness of any information, apparatus, product or process disclosed, or represents that its use would not infringe privately owned rights.

Printed in the United States of America

Available From the National Technical Information Service, U.S. Department of Commerce, 5285 Port

Royal Road, Springfield, Virginia 22161.

Price: Microfiche $\$ 3.00$

Paper Copy $\$ 4.506 .4$ 
BDX-613-2416

\section{MASTER}

Distribution Category UC-38

THUMB TACK PHYSICAL MODEL EVALUATION

OF POLYSTYRENE BEAD FOAM AS AN

ENCAPSULANT FOR ELECTRONIC PACKAGES

By D. J. Fossey

and

G. D. Swanson

Published March 1980

Topical Report

D. J. Fossey, Project Leader

Project Team:

D. C. Dyer

L. L. Holland

G. D. Swanson

This book was prepared as an account of work sponsored by an agency of the United States Government

Neither the United States Government nor any agency thereof, nor any of theis enployees, makes any

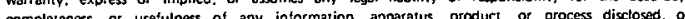

completenss.

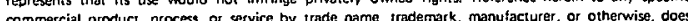

not necessarily consciwis or imply is endarsement, recommendation, or fovoring by the Unites

States Government or any agency thereof. The views and opinions of authors expressed herein do nor

necesserily state or reflect those of the United States Government or any ogency thereot.

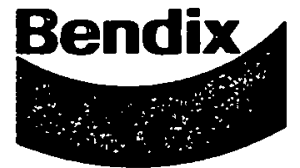

Kansas City Division 
THUMB TACK PHYSICAL MODEL EVALUATION OF POLYSTYRENE BEAD FOAM AS AN ENCAPSULANT. FOR ELECTRONIC PACKAGES

BDX-613-2416, Topical Report, Published March 1980.

Prepared by D. J. Fossey and G. D. Swanson

A physical model in the shape of a thumb tack is used to measure forces on electronic component lead wires when soldered into printed wiring boards. Encapsulation of electronic packages in polystyrene bead foam of $0.2,0.3,0.4,0.5$, and $0.6 \mathrm{~g} / \mathrm{cm}^{3}$ densities was evaluated. No solder joint damage was seen. Crushing pressures on metal transistors also were safe for all densities. Experimental data agreed well with theoretical calculations based on the concept of constrained thermal expansion.

FOA/drb

This report was prepared as an account of work sponsored by the United States Government. Neither the United States, nor the United States Depertment of Energy, nor any of their employees, nor any of their contractors, subcontractors. or their employees. makes any warranty, expressed or implied or assumes any legal liability or responsibility for the accuracy, completeness or usefulness of any information. apparatus, product, or process disclosed, or represents that its use would not infringe privately owned rights.
The Bendix Corporation Kansas City Division P. O. Box 1159

Kansas City, Missouri 64141

A prime contractor with the United States Department of Energy under Contract Number DE-AC04-76-DPOO613 


\section{CONTENTS}

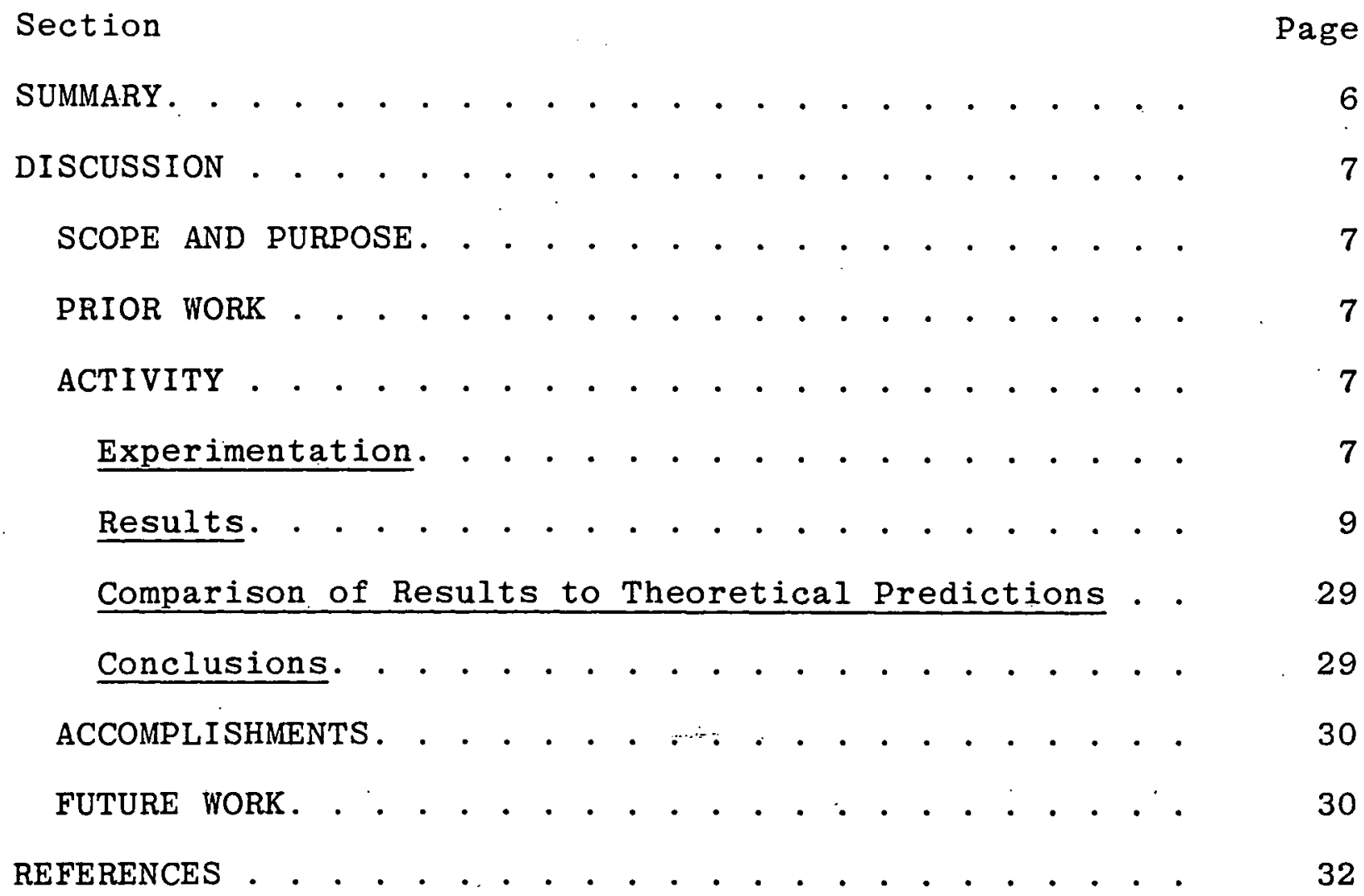




\section{ILLUSTRATIONS}

Figure

Page

1

2

3

4

5

6

7

8

9 .

10

11

12

13

14

15

Fully Instrumented Thumb Tack Soldered Into

a PWB (P95508). . . . . . . . . . .

Instrumented Extensometer Mounted on a PWB and Soldered to Lead Extension (P95507). .

9

Loads and Pressures Developed During PSBF

Fusion Cycle. . . . . . . . . . . . . .

Loads for a Thermal Cycle of $0.2 \mathrm{~g} / \mathrm{cm}^{3}$

PSBF Encapsulation. . . . . . . . . . .

Loads for First Thermal Cycle of First

$0.3 \mathrm{~g} / \mathrm{cm}^{3}$ PSBF Encapsulation. ... . . . .

Pressures for First Thermal Cycle of First $0.3 \mathrm{~g} / \mathrm{cm}^{3}$ PSBF Encapsulation. . . . . . .

Loads for Thermal Cycle of Second $0.3 \mathrm{~g} / \mathrm{cm}^{3}$ PSBF Encapsulation. . . . . . . . . . . .

Pressures for Thermal' Cycle of Second $0.3 \mathrm{~g} / \mathrm{cm}^{3}$ PSBF Encapsulation. . . . . .

Loads for First Thermal Cycle of $0.4 \mathrm{~g} / \mathrm{cm}^{3}$ PSBF Encapsulation. . . . . . . . . . . .

Pressures for First Thermal Cycle of $0.4 \mathrm{~g} / \mathrm{cm}^{3} \mathrm{PSBF}$ Encapsulation. . . . . . .

Loads for First Thermal Cycle of $0.5 \mathrm{~g} / \mathrm{cm}^{3}$ PSBF Encapsulation. . . . . . . . . . .

Pressures for First Thermal Cycle of $0.5 \mathrm{~g} / \mathrm{cm}^{3}$ PSBF Encapsulation. . . . . . .

Loads for First Thermal Cycle of $0.6 \mathrm{~g} / \mathrm{cm}^{3}$ PSBF Encapsulation (3.6-Percent Initial Pentane Content). . . . . . . . . . . .

Pressures for First Thermal Cycle of $0.6 \mathrm{~g} / \mathrm{cm}^{3}$ PSBF Encapsulation (3.6-Percent Initial Pentane Content). . . . . . . . . .

Loads for First Thermal Cycle of $0.6 \mathrm{~g} / \mathrm{cm}^{3}$ PSBF Encapsulation (6-Percent Initial Pentane Content) 
Pressures for First Thermal Cycle of

$0.6 \mathrm{~g} / \mathrm{cm}^{3}$ PSBF Encapsulation (6-Percent

Initial Pentane Content) . . . . . . . .

\section{TABLES}

Number

Page

1

Thumb Tack Data at $24^{\circ} \mathrm{C}$ After Fusion Cycle of PSBF. . . . . . . . . . . . . . . .

Data Changes From $-54^{\circ} \mathrm{C}$ to $74^{\circ} \mathrm{C}$ During

Thermal Cycles for PSBF. . . . . . . . . 


\section{SUMMARY}

This evaluation of polystyrene bead foam (PSBF) as an encapsulant for electronic components using the thumb tack physical model was one task in the overall encapsulant evaluation for an electronic assembly. Two thumb tack models were encapsulated in PSBF with densities of $0.3,0.4,0.5$ and $0.6 \mathrm{~g} / \mathrm{cm}^{3}$; previously reported data from $0.2 \mathrm{~g} / \mathrm{cm}^{3}$ PSBF are included. The $0.6 \mathrm{~g} / \mathrm{cm}^{3} \mathrm{PSBF}$ density was evaluated for 3.6 and 6 percent initial pentane content. Load in the lead wire connecting the tack lead to the solder joint, movement in the solder joint, and crushing pressure on a transistor were measured for all conditions.

It was found that the loads and pressures generated by all densities of PSBF were safe, and that densities from 0.4 to $0.6 \mathrm{~g} / \mathrm{cm}^{3}$ produced nearly the same thermomechanical stress effects. The lead wires did not move in the solder joints. Good agreement was seen between the experimental data and theoretical calculations based on a constrained thermal expansion formula. Thus, theoretical calculations are reliable for estimating expected loads on different specific materials and component geometries. 


\section{DISCUSSION}

\section{SCOPE AND PURPOSE}

One laboratory task in the evaluation of polystyrene bead foam (PSBF) for encapsulation of electronic components was to measure loads caused by the PSBF fusion process and subsequent thermal cycles. The thumb tack transducers were chosen to act as generalized physical models of electronic components soldered normal to a printed wiring board (PWB) and loaded axially. The axial forces would then be measured for encapsulation in PSBF of 0.1 , $0.3,0.4,0.5$, and $0.6 \mathrm{~g} / \mathrm{cm}^{3}$ densities. Any movement in the joint would be measured with extensometers. Pressure transducers made by strain gaging transistors also were included.

\section{PRIOR WORK}

The technique for mounting three strain gages about an electronic component lead wire was developed on an earlier encapsulant stress evaluation and has been published in the open literature. ${ }^{1}$ The technique has been applied in earlier tests on glass microballoons (GMB)/epoxy encapsulation and other tests on $0.3 \mathrm{~g} / \mathrm{cm}^{3}$ PSBF and $0.1,0.2$, and $0.33 \mathrm{~g} / \mathrm{cm}^{3}$ polyurethane foam (PUF) encapsulation. ${ }^{2}$

\section{ACTIVITY}

The thumb tack test technique was designed to evaluate axial loads on a component lead wire soldered normal to a PWB. The thumb tacks serve as generalized models of electronic components. The force generated by a temperature change and transmitted to the solder joint connecting the tack to a PWB can then be measured for a consistent geometry for the encapsulant materials of interest. The present evaluation included PSBF of $0.3,0.4,0.5$, and $0.6 \mathrm{~g} / \mathrm{cm}^{3}$ densities. PSBF of $0.2 \mathrm{~g} / \mathrm{cm}^{3}$ previously had been evaluated, ${ }^{2}$ and $0.1 \mathrm{~g} / \mathrm{cm}^{3}$ density could not be fused without structural collapse.

\section{Experimentation}

Each thumb tack transducer (Figure 1) consisted of a 6.35-mmdiameter steel disc welded to a $0.813-\mathrm{mm}$-diameter copper lead wire. Each lead was prestressed by stretching with a $111.8 \mathrm{~N}$ load. Strain gages then were bonded to the copper lead at 120-degree spacings about the lead, and the lead was load calibrated. The lead was soldered with $60 \mathrm{Sn}-4 \mathrm{OPb}$ solder into a $1.270-\mathrm{mm}$-diameter hole in a $0.671-\mathrm{mm}-$ thick PWB disc $51 \mathrm{~mm}$ in diameter. An extensometer (Figure 2) was attached to the copper lead extension on 


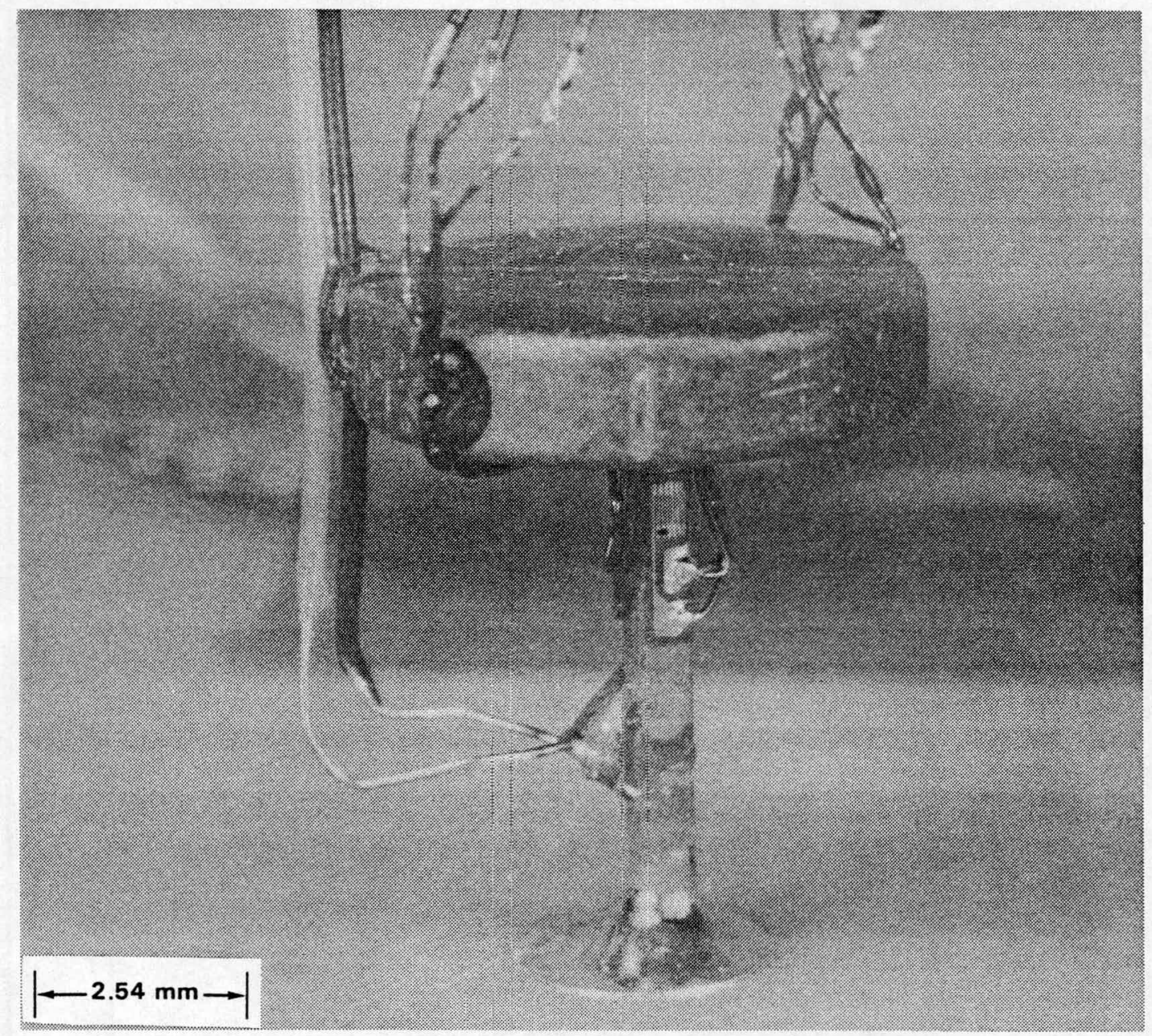

Figure 1. Fully Instrumented Thumb Tack Soldered Into a PWB

the PWB side opposite the tack head and protected by a housing made of PUF. A pressure transducer, made from a strain gaged and calibrated transistor, was mounted on the PWB adjacent to each extensometer. Thermocouples monitored temperature at each strain gage location.

Each thumb tack unit was mounted in a $51-\mathrm{mm}$-diameter metal tube, filled with the appropriate density of pre-expanded polystyrene beads, then placed in an oven preheated to $105^{\circ} \mathrm{C}$ and held for 20 minutes above $93^{\circ} \mathrm{C}$. The units then were thermal cycled from $-54^{\circ} \mathrm{C}$ to $74^{\circ} \mathrm{C}$ at least three times. Two thumb tacks encapsulated with each density of PSBF were tested. The PSBF was then dissolved in toluene which was agitated by bubbling air. All transducers were checked, and the thumb tacks then were encapsulated in the next higher density of PSBF. 


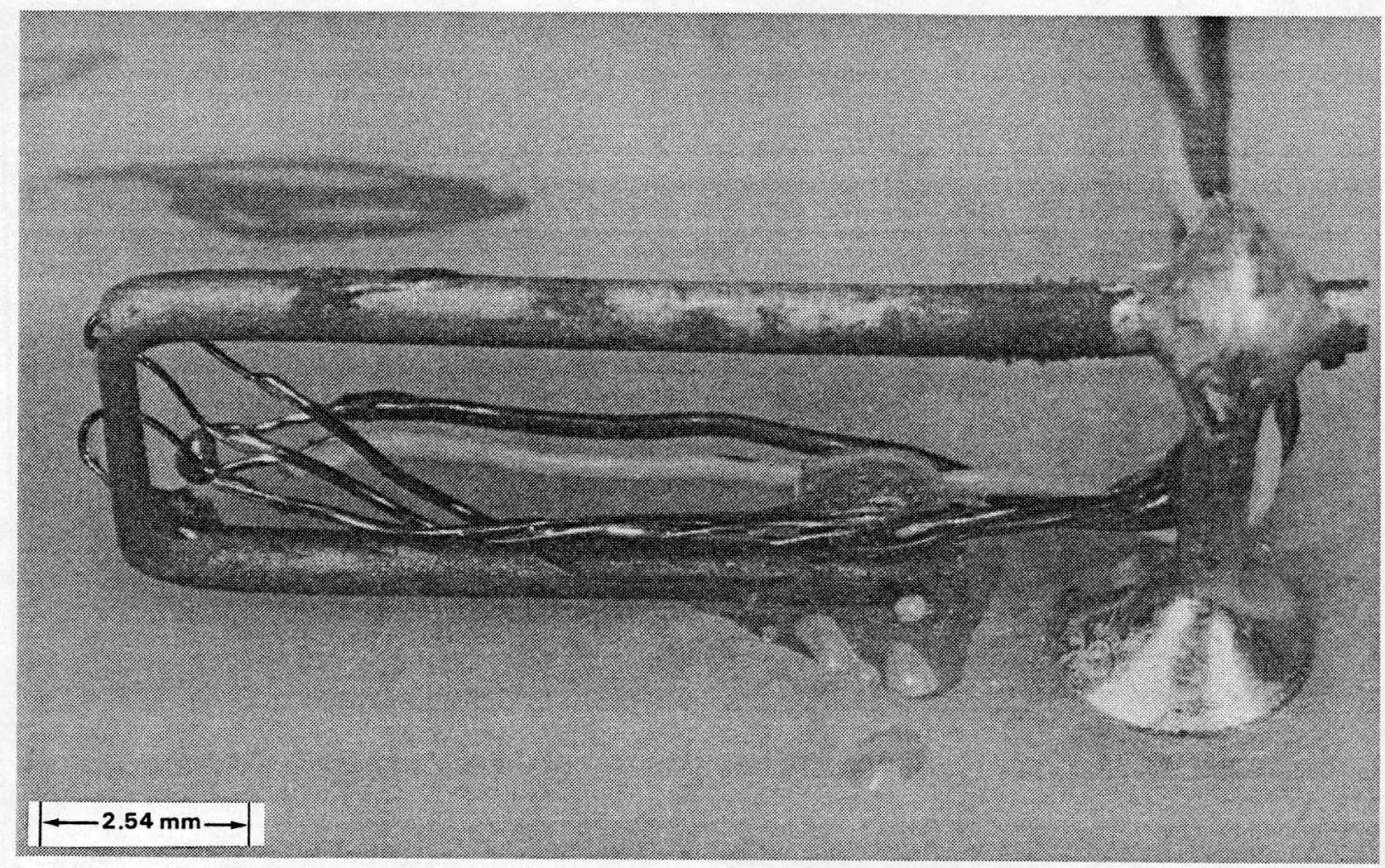

Figure 2. Instrumented Extensometer Mounted on a PWB and Soldered to Lead Extension

\section{Results}

Table 1 lists the PSBF densities; the residual pentane content; and the measured load, deflection, and pressure data for each thumb tack at $24^{\circ} \mathrm{C}$ after the PSBF fusion cycle. The loads and pressures developed during the fusion cycle are shown graphically in Figure 3. The minus sign in front of the load values indicate that the load was compressive. Note the low load for the repeat test of $0.3 \mathrm{~g} / \mathrm{cm}^{3}$. This foam was fused a shorter time at temperature because some melt-back around the container walls had occurred for the first $0.3 \mathrm{~g} / \mathrm{cm}^{3}$ test. The shorter time at temperature cured the melt-back problem, but may have produced a foam so friable that cracking reduced the force directly transmitted to the thumb tack. No melt-back occurred for any other density of PSBF.

In general, the loads and deflections increased and the pressure decreased as the PSBF density increased. The loads generated by the 0.5 and $0.6 \mathrm{~g} / \mathrm{cm}^{3}$ were essentially the same and equivalent to the load previously reported for $0.2 \mathrm{~g} / \mathrm{cm}^{3}$ PUF. ${ }^{2}$ 
Table 1. Thumb Tack Data at $24^{\circ} \mathrm{C}$ After Fusion Cycle of PSBF

\begin{tabular}{|c|c|c|c|c|c|c|c|}
\hline \multirow{2}{*}{$\begin{array}{l}\text { Density } \\
\left(\mathrm{g} / \mathrm{cm}^{3}\right)\end{array}$} & \multirow{2}{*}{$\begin{array}{l}\text { Residual } \\
\text { Volatiles } \\
\text { (Percent) }\end{array}$} & \multicolumn{2}{|c|}{ Load $(\mathrm{N})$} & \multicolumn{2}{|c|}{ Deflection ( $\mu \mathrm{m})$} & \multicolumn{2}{|c|}{ Pressure ( $\mathrm{kPa})$} \\
\hline & & Tack 1 & Tack 2 & Tack 1 & Tack 2 & Tack 1 & Tack 2 \\
\hline 0.2 & 1.4 & -15.6 & -17.4 & -2.5 & +5.0 & & \\
\hline $0.3-1$ & 1.5 & -10.2 & -6.7 & -5.1 & -2.5 & 33.8 & 11.7 \\
\hline $0.3-2$ & 1.5 & -2.2 & -2.2 & -15.2 & -15.2 & 36.2 & 10.3 \\
\hline 0.4 & 2.5 & -11.6 & -12.0 & -7.6 & -10.2 & 8.3 & 6.9 \\
\hline 0.5 & 2.7 & -24.5 & -24.0 & -7.6 & -20.3 & 4.8 & 15.2 \\
\hline $0.6-1 *$ & 2.3 & -22.7 & -21.4 & -35.6 & -17.8 & 28.9 & 20.7 \\
\hline $0.6-2 *$ & 3.7 & -22.2 & -20.5 & -17.8 & -17.8 & 15.8 & 18.6 \\
\hline
\end{tabular}

*0.6-1 had 3.6-percent initial pentane content; $0.6-2$ had 6 -percent initial pentane content. 
Table 2 summarizes the range of load, deflection, and pressure generated on each thumb tack during thermal cycle testing. Agreement between the two thumb tacks was exceptionally good for load. However, Tack 1 usually had higher deflections and pressures than Tack 2. No reason is known which can explain such a coincidence. The pressure difference between the two thumb tacks with the same PSBF density may be related to a variation in filling the volume below the PWB from one tack to the next and to a different influence from the adjacent PUF housing for the extensometer.

The load range shown in Table 2 did not change greatly from 0.4 through $0.6 \mathrm{~g} / \mathrm{cm}^{3}$ density encapsulations. This means that all PSBF densities in this range will produce nearly the same load range on solder joints of component lead wires when thermal cycled. ${ }^{2}$ The severity of the range of loading was equivalent to $0.1 \mathrm{~g} / \mathrm{cm}^{3}$ PUF encapsulation. It was a significantly lower load range than developed for 0.2 or $0.33 \mathrm{~g} / \mathrm{cm}^{3}$ PUF or GMB/epoxy encapsulation.

Figures 4 through 16 show the temperature and the corresponding load and pressure for the first thermal cycle for all tests. Subsequent thermal cycles for a given test were nearly identical and therefore are not shown. All deflections were small, with very little change over a thermal cycle; therefore; deflections are not shown.

Behavior of the load on the thumb tack during thermal cycling was the same for all densities of PSBF. The compressive load increased as the PSBF was cooled to $-54^{\circ} \mathrm{C}$ and decreased as the temperature was raised to $74^{\circ} \mathrm{C}$. At about $40^{\circ} \mathrm{C}$, the load became tensile and then changed back to a compressive load at $74^{\circ} \mathrm{C}$. The compressive load increased slightly as the PSBF cooled to room temperature.

The transient tensile load at $40^{\circ} \mathrm{C}$ may have resulted from the outer layers of PSBF being at a higher temperature and exerting a tensile load on the PSBF next to the transducer. This tensile load could have been caused by thermal expansion. The tensile load was relieved as the temperature throughout the PSBF equilibrated at $74^{\circ} \mathrm{C}$. Because these transient loads were at a low level near zero, no mechanical loading problems are anticipated.

The pressures generated during thermal cycling appeared to be more dependent on the density of the PSBF. As the PSBF cooled to $-54^{\circ} \mathrm{C}$, the pressure increased by 20 to $120 \mathrm{kPa}$. The higher PSBF densities generated more pressure. Mixed results were obtained for the pressures generated by the various PSBF densities during the remaining portion of the thermal cycle. In most cases a negative pressure was recorded as the PSBF was heated to $74^{\circ} \mathrm{C}$. This negative pressure indicated that the pressure transducer was recording a small ( 6 to $70 \mathrm{kPa}$ ) tensile stress. This tensile stress also was noted in the tensile load mentioned above. 

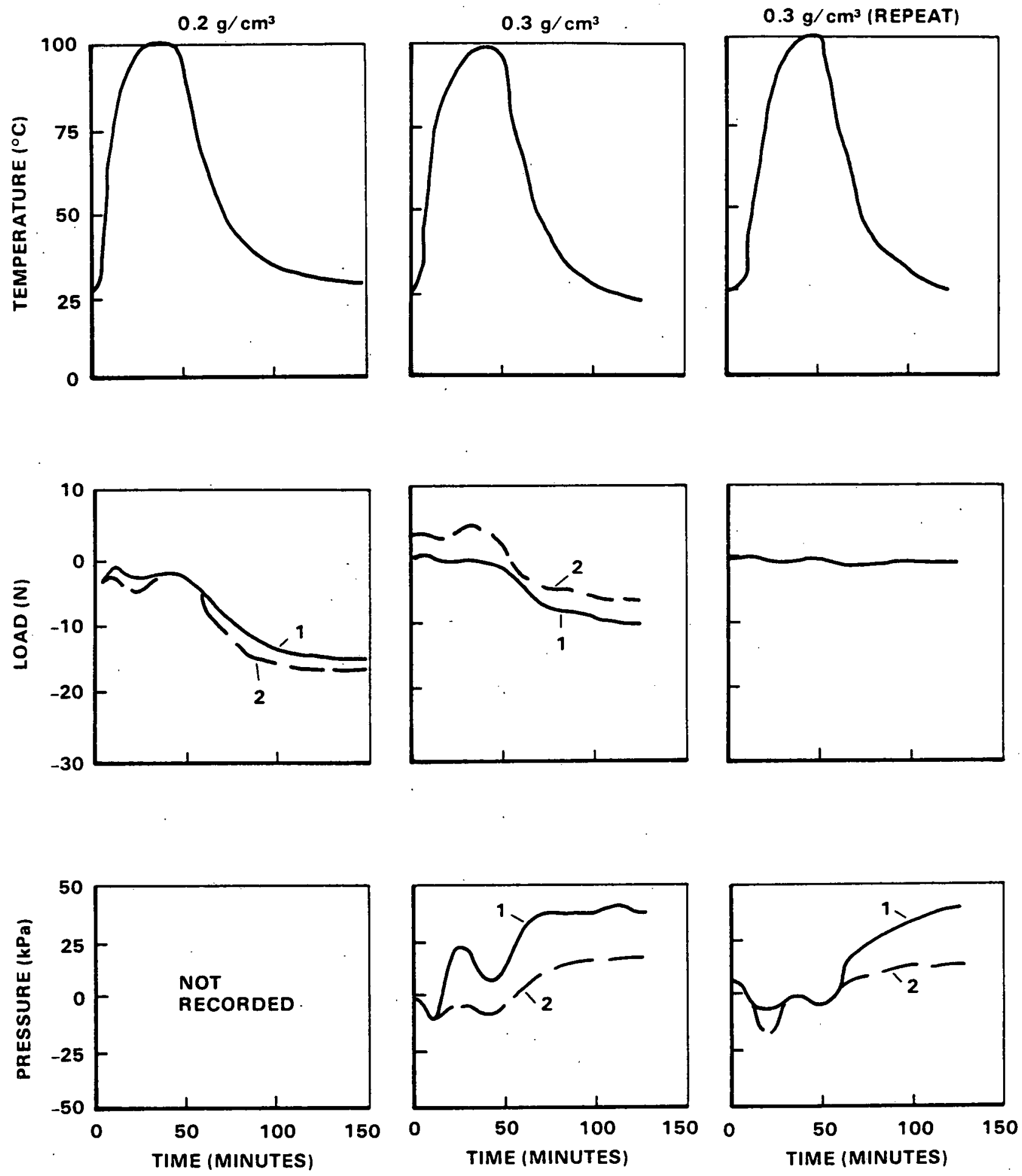

Figure 3. Loads and Pressures Developed During PSBF Fusion Cycle 

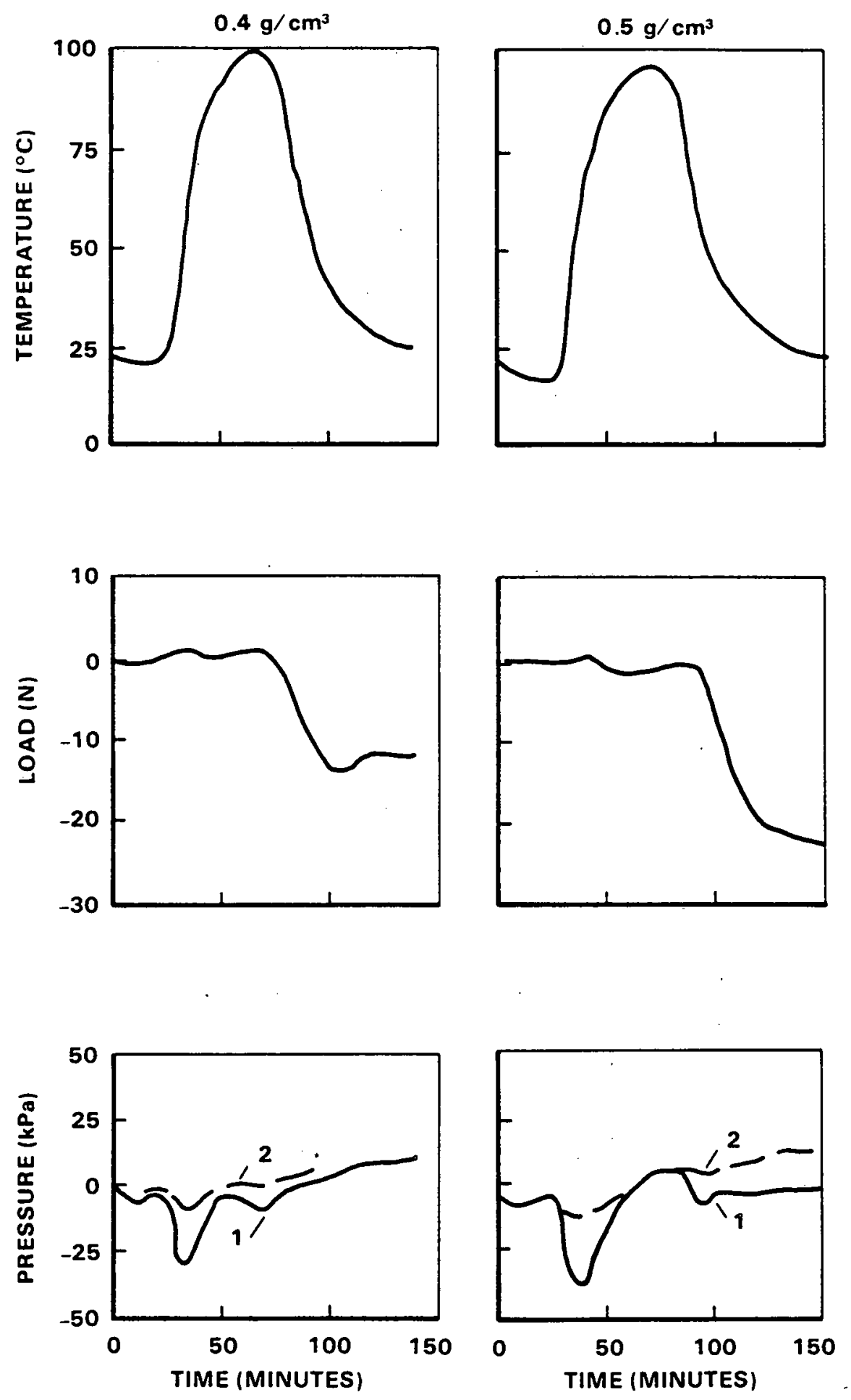

Figure 3 Continued. Loads and Pressures Developed During PSBF Fusion Cycle 


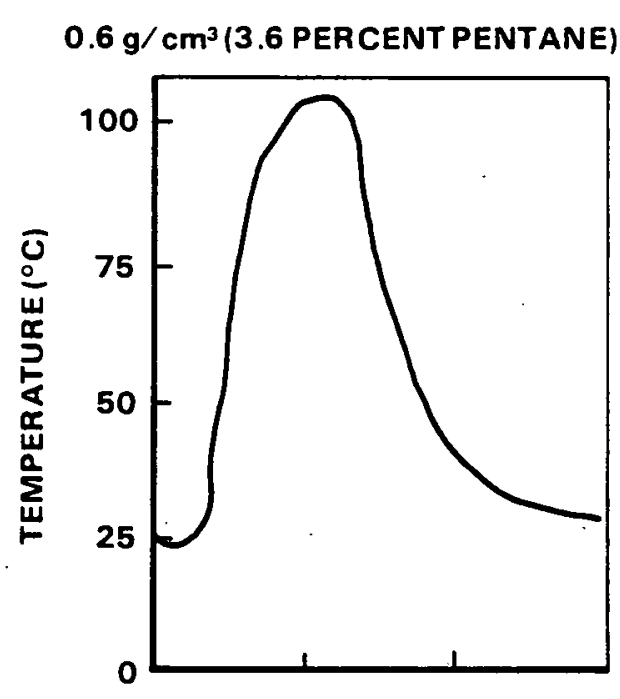

$0.6 \mathrm{~g} / \mathrm{cm}^{3}$ (6 PERCENT PENTANE)
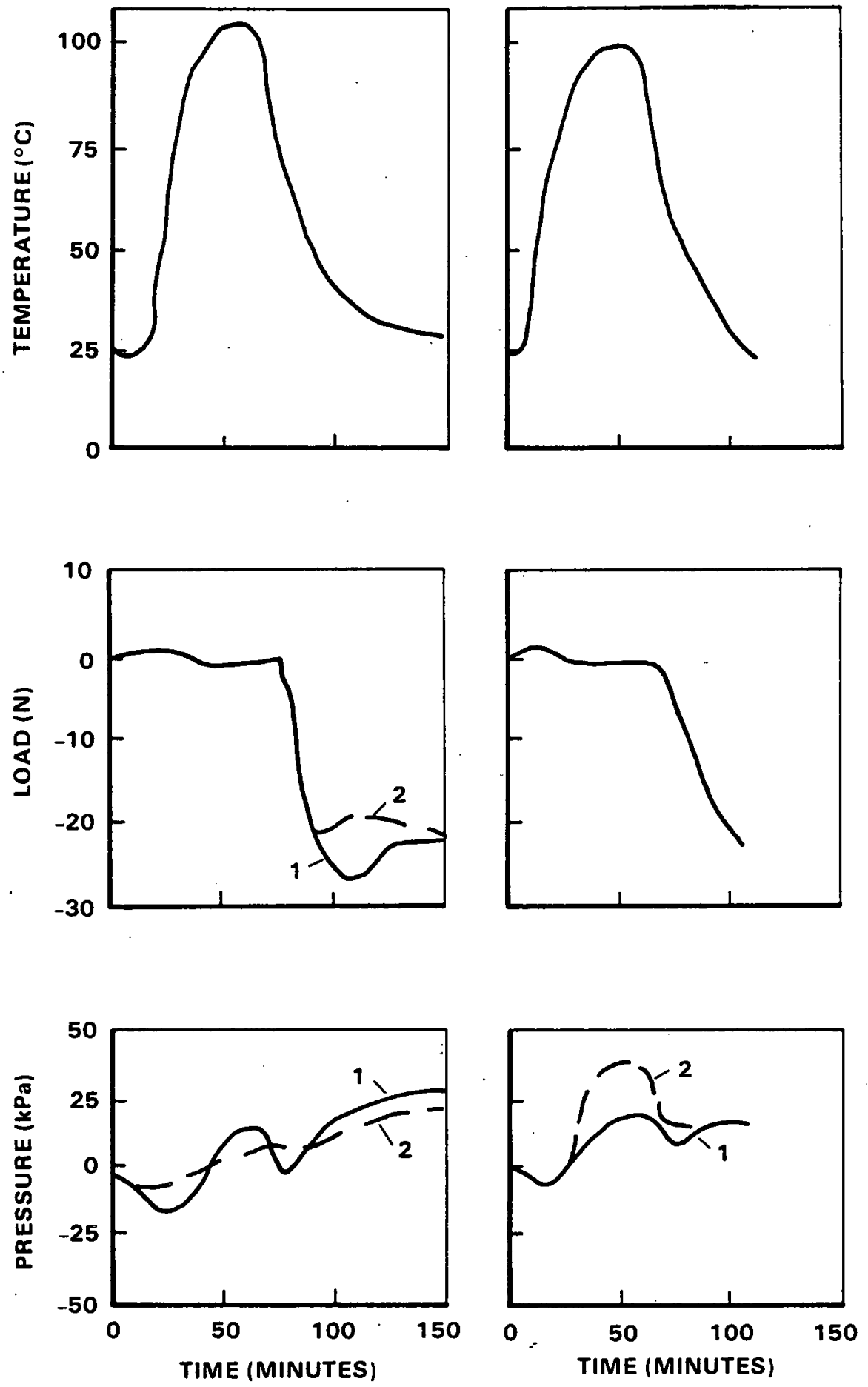

Figure 3 Continued. Loads and Pressures Developed During PSBF Fusion Cycle 
Table 2. Data Changes From $-54^{\circ} \mathrm{C}$ to $74^{\circ} \mathrm{C}$ During Thermal Cycles for PSBF

\begin{tabular}{|c|c|c|c|c|c|c|c|c|c|c|}
\hline \multirow{2}{*}{$\begin{array}{l}\text { Density } \\
\left(\mathrm{g} / \mathrm{cm}^{3}\right)\end{array}$} & \multirow{2}{*}{$\begin{array}{l}\text { Thermal } \\
\text { Cycle }\end{array}$} & \multicolumn{3}{|c|}{ Temperature $\left({ }^{\circ} \mathrm{C}\right)$} & \multicolumn{2}{|c|}{$\begin{array}{l}\text { Load } \\
\text { Change (N) }\end{array}$} & \multicolumn{2}{|c|}{$\begin{array}{l}\text { Deflection } \\
\text { Change }(\mu \mathrm{m})\end{array}$} & \multicolumn{2}{|c|}{$\begin{array}{l}\text { Pressure } \\
\text { Change ( } \mathrm{kPa})\end{array}$} \\
\hline & & Minimum & Maximum & Change & Tack 1 & Tack 2 & Tack 1 & Tack 2 & Tack 1 & Tack 2 \\
\hline 0.2 & 1 & -57 & 85 & 142 & 25.8 & 42.3 & 7.5 & 15.2 & & \\
\hline $0.3-1$ & $\begin{array}{l}1 \\
2 \\
3\end{array}$ & $\begin{array}{l}-55 \\
-54 \\
-55\end{array}$ & $\begin{array}{l}77 \\
81 \\
78\end{array}$ & $\begin{array}{l}132 \\
135 \\
133\end{array}$ & $\begin{array}{l}36.5 \\
39.1 \\
38.7\end{array}$ & $\begin{array}{l}38.7 \\
42.7 \\
43.1\end{array}$ & $\begin{array}{l}5.1 \\
5.1 \\
2.5\end{array}$ & $\begin{array}{r}7.6 \\
10.2 \\
12.7\end{array}$ & $\begin{array}{r}99.2 \\
111.6 \\
110.9\end{array}$ & $\begin{array}{l}63.4 \\
69.6 \\
74.4\end{array}$ \\
\hline $0.3-2$ & $\begin{array}{l}1 \\
2 \\
3 \\
4\end{array}$ & $\begin{array}{l}-57 \\
-56 \\
-54 \\
-54\end{array}$ & $\begin{array}{l}71 \\
72 \\
77 \\
72\end{array}$ & $\begin{array}{l}128 \\
128 \\
131 \\
126\end{array}$ & $\begin{array}{l}21.8 \\
19.6 \\
19.1 \\
18.7\end{array}$ & $\begin{array}{l}21.4 \\
18.2 \\
17.8 \\
16.9\end{array}$ & $\begin{array}{l}12.7 \\
15.2 \\
20.3 \\
17.8\end{array}$ & $\begin{array}{l}5.1 \\
0.0 \\
0.0 \\
0.0\end{array}$ & $\begin{array}{l}72.3 \\
68.9 \\
67.5 \\
66.1\end{array}$ & $\begin{array}{l}37.2 \\
31.0 \\
50.3 \\
11.0\end{array}$ \\
\hline 0.4 & $\begin{array}{l}1 \\
2 \\
3 \\
4\end{array}$ & $\begin{array}{l}-58 \\
-57 \\
-59 \\
-56\end{array}$ & $\begin{array}{l}71 \\
79 \\
73 \\
77\end{array}$ & $\begin{array}{l}129 \\
136 \\
132 \\
133\end{array}$ & $\begin{array}{l}44.5 \\
47.1 \\
44.0 \\
45.8\end{array}$ & $\begin{array}{l}48.9 \\
48.9 \\
48.5 \\
52.0\end{array}$ & $\begin{array}{l}15.2 \\
17.8 \\
15.2 \\
17.8\end{array}$ & $\begin{array}{l}0.0 \\
0.0 \\
0.0 \\
0.0\end{array}$ & $\begin{array}{r}90.9 \\
117.1 \\
111.6 \\
124.7\end{array}$ & $\begin{array}{l}47.5 \\
53.7 \\
57.9 \\
71.0\end{array}$ \\
\hline 0.5 & $\begin{array}{l}1 \\
2 \\
3 \\
4\end{array}$ & $\begin{array}{l}-56 \\
-57 \\
-54 \\
-55\end{array}$ & $\begin{array}{l}82 \\
78 \\
73 \\
74\end{array}$ & $\begin{array}{l}138 \\
135 \\
127 \\
129\end{array}$ & $\begin{array}{l}52.0 \\
50.7 \\
48.0 \\
49.8\end{array}$ & $\begin{array}{l}48.0 \\
52.5 \\
51.6 \\
50.3\end{array}$ & $\begin{array}{l}22.9 \\
17.8 \\
15.2 \\
17.8\end{array}$ & $\begin{array}{l}5.1 \\
0.0 \\
2.5 \\
2.5\end{array}$ & $\begin{array}{l}58.6 \\
* \\
* \\
98.5\end{array}$ & $\begin{array}{l}60.6 \\
* \\
* \\
66.8\end{array}$ \\
\hline $0.6-1 * *$ & $\begin{array}{l}1 \\
2 \\
3 \\
4\end{array}$ & $\begin{array}{l}-58 \\
-55 \\
-56 \\
-56\end{array}$ & $\begin{array}{l}74 \\
73 \\
73 \\
75\end{array}$ & $\begin{array}{l}132 \\
128 \\
129 \\
131\end{array}$ & $\begin{array}{l}44.5 \\
38.3 \\
40.0 \\
37.8\end{array}$ & $\begin{array}{l}53.8 \\
49.4 \\
49.4 \\
49.4\end{array}$ & $\begin{array}{r}30.5 \\
2.5 \\
10.2 \\
7.6\end{array}$ & $\begin{array}{l}* * * \\
* * * \\
* * * \\
* * *\end{array}$ & $\begin{array}{l}193.6 \\
171.6 \\
173.6 \\
167.4\end{array}$ & $\begin{array}{l}97.8 \\
81.3 \\
92.3 \\
85.4\end{array}$ \\
\hline $0.6-2 * *$ & $\begin{array}{l}1 \\
2 \\
3 \\
4 \\
5\end{array}$ & $\begin{array}{l}-54 \\
-55 \\
-59 \\
-54 \\
-55\end{array}$ & $\begin{array}{l}75 \\
74 \\
75 \\
77 \\
75\end{array}$ & $\begin{array}{l}129 \\
129 \\
134 \\
131 \\
130\end{array}$ & $\begin{array}{l}49.8 \\
50.3 \\
50.7 \\
52.9 \\
52.0\end{array}$ & $\begin{array}{l}47.1 \\
48.9 \\
50.7 \\
46.7 \\
51.2\end{array}$ & $\begin{array}{l}22.9 \\
20.3 \\
20.3 \\
20.3 \\
20.3\end{array}$ & $\begin{array}{l}2.5 \\
2.5 \\
2.5 \\
0.0 \\
2.5\end{array}$ & $\begin{array}{l}115.8 \\
111.6 \\
137.8 \\
128.8 \\
132.3\end{array}$ & $\begin{array}{l}73.0 \\
61.3 \\
55.8 \\
53.1 \\
66.8\end{array}$ \\
\hline
\end{tabular}

* Amplifier batteries ready for replacement

**Initial pentane content for $0.6-1$ was 3.6 percent and for $0.6-2$ was 6 percent.

***obviously incorrect data. 

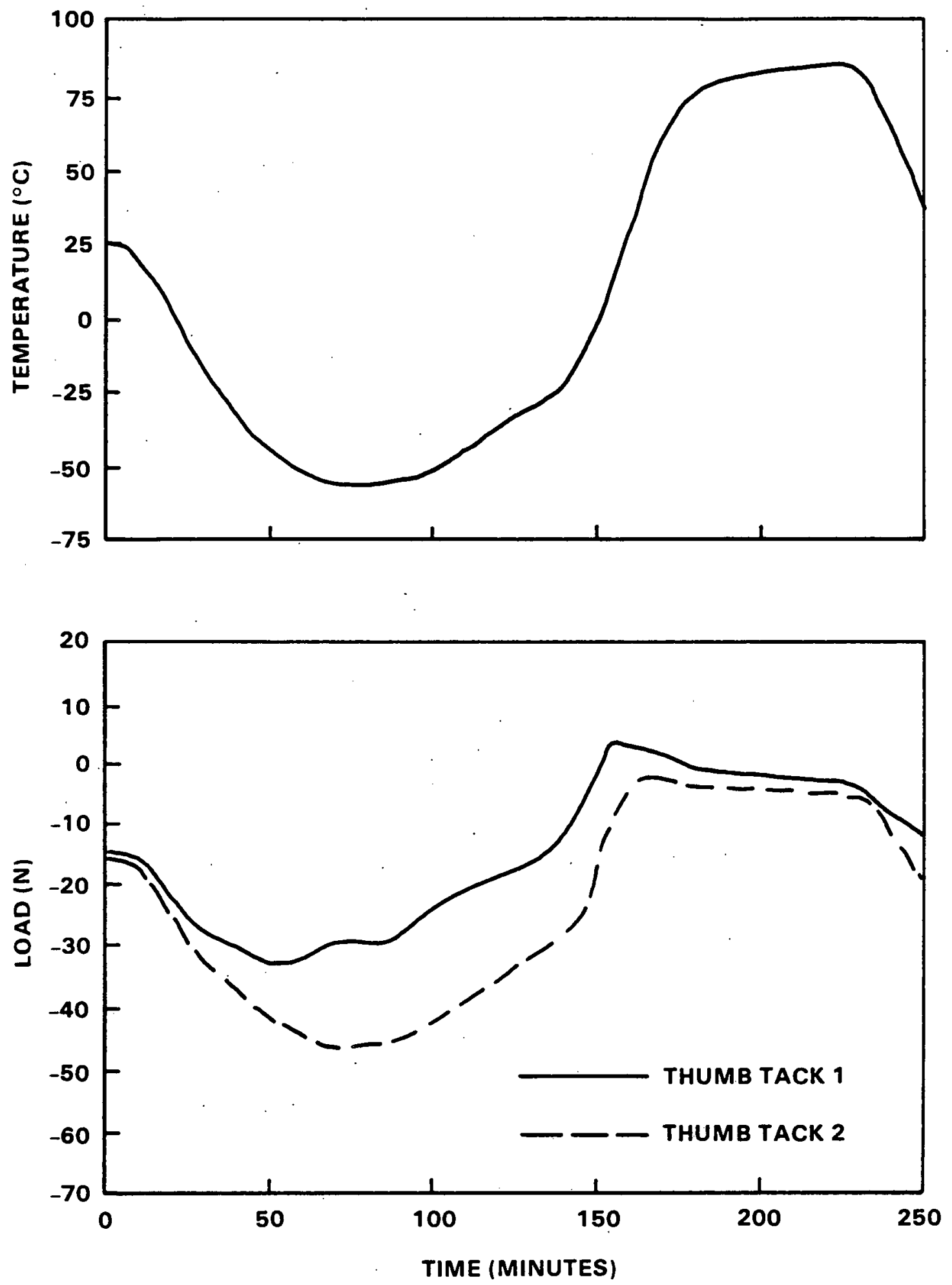

Figure 4. Loads for a Thermal Cycle of $0.2 \mathrm{~g} / \mathrm{cm}^{3}$ PSBF Encapsulation 

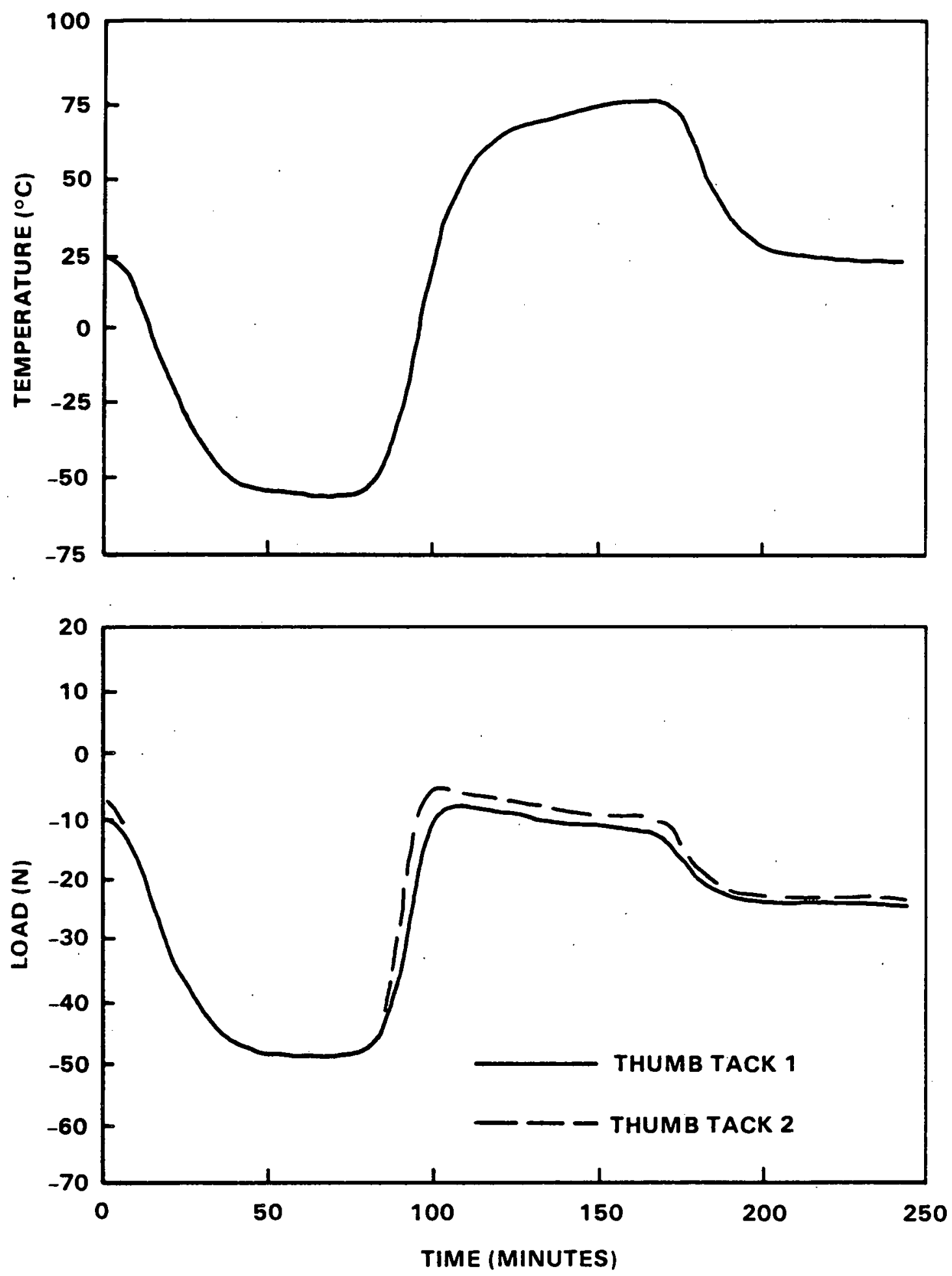

Figure 5. Loads for First Thermal Cycle of First $0.3 \mathrm{~g} / \mathrm{cm}^{3}$ PSBF Encapsulation 

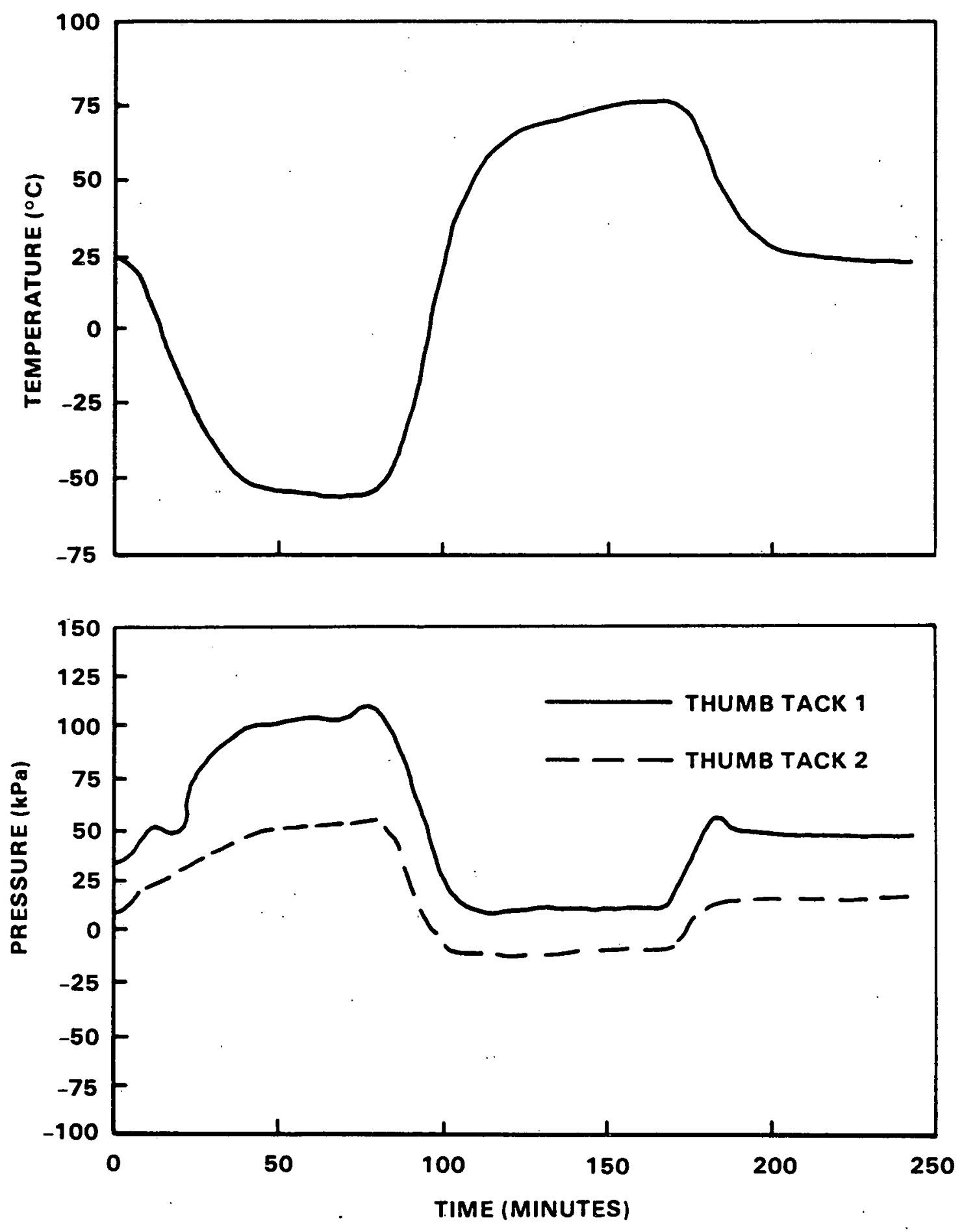

Figure 6. Pressures for First Thermal Cycle of First $0.3 \mathrm{~g} / \mathrm{cm}^{3}$ PSBF Encapsulation 

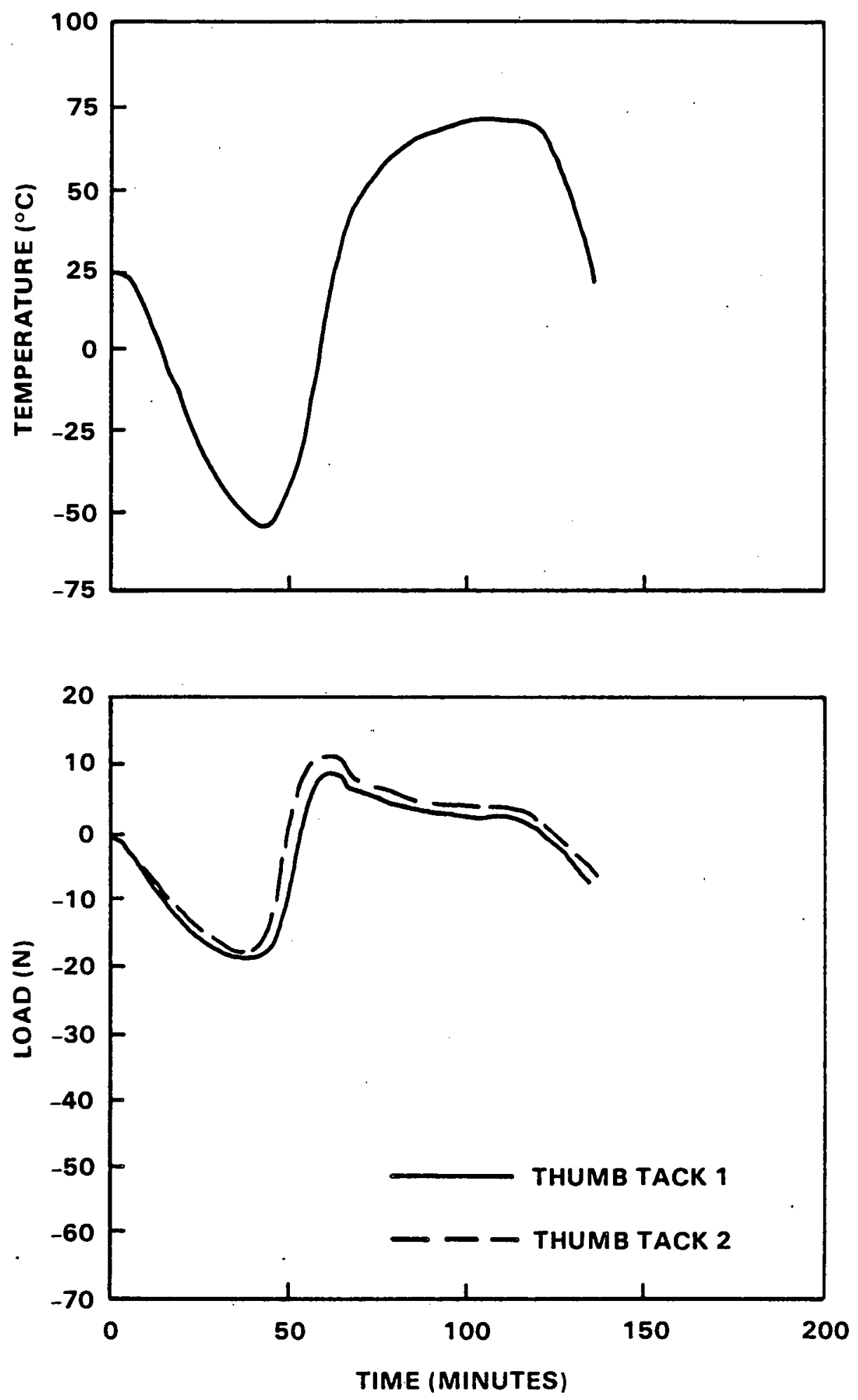

Figure 7. Loads for Thermal Cycle of Second $0.3 \mathrm{~g} / \mathrm{cm}^{3}$ PSBF Encapsulation 

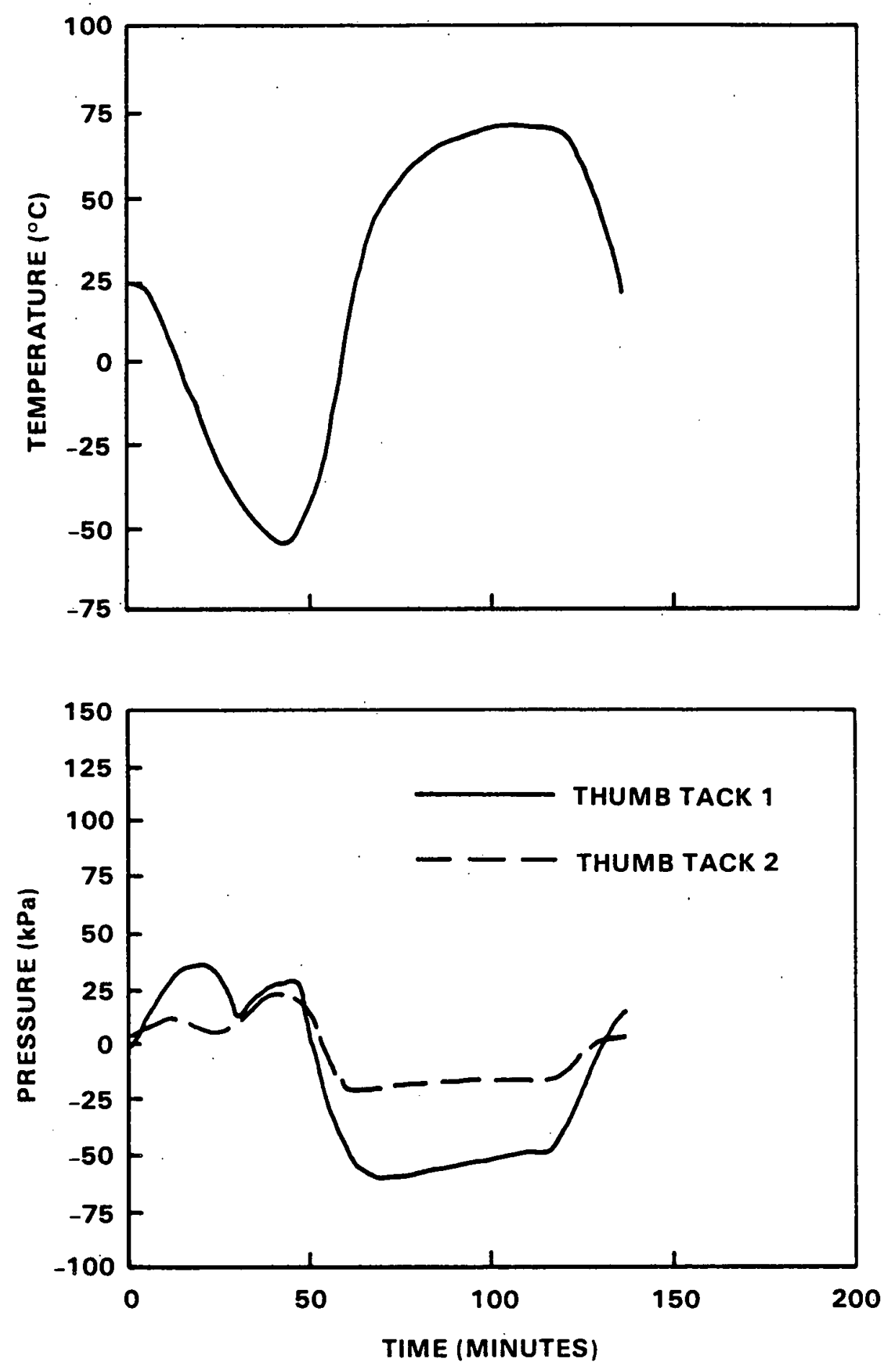

Figure 8. Pressures for Thermal Cycle of Second $0.3 \mathrm{~g} / \mathrm{cm}^{3}$ PSBF Encapsulation 

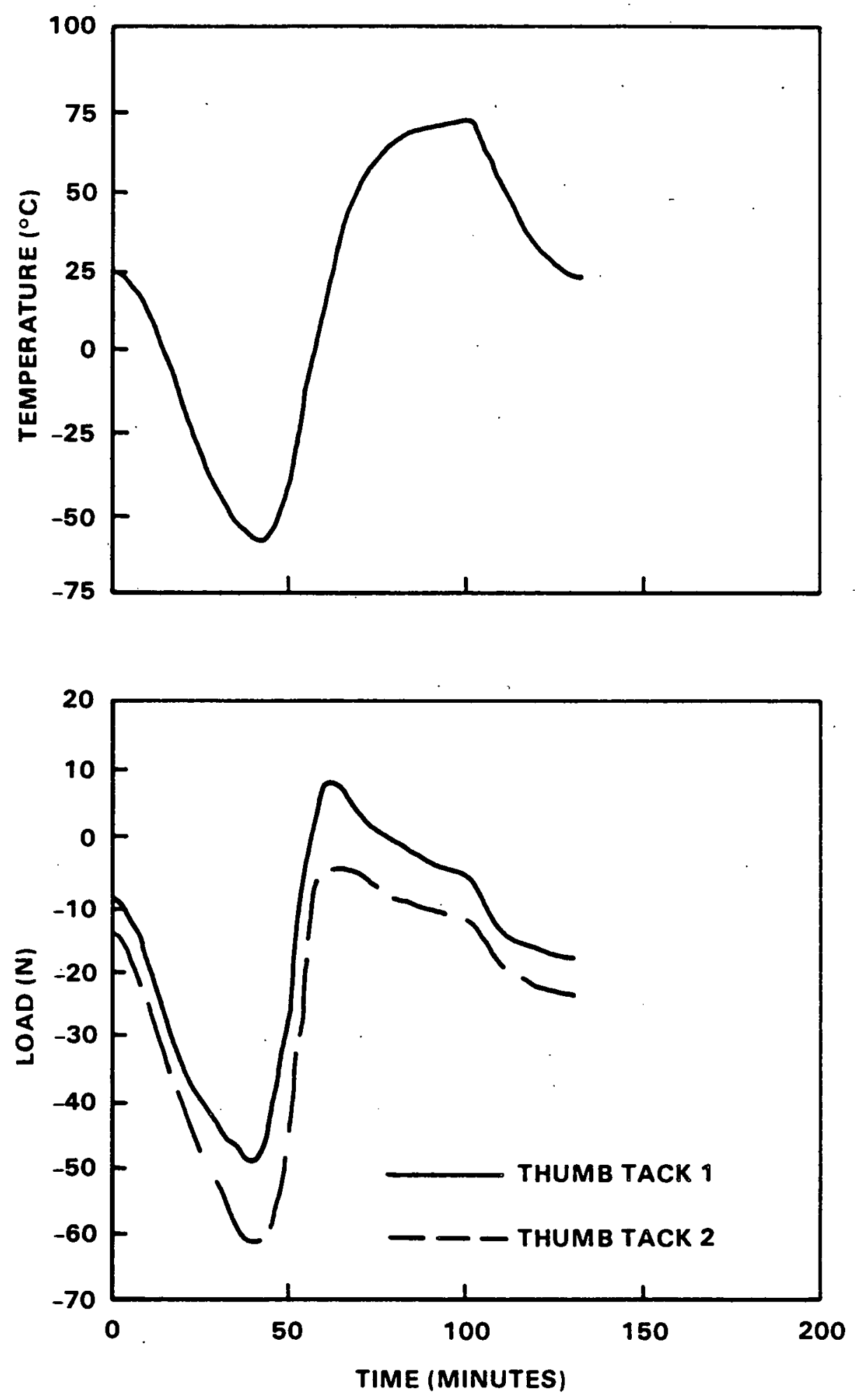

Figure 9. Loads for First Thermal Cycle of $0.4 \mathrm{~g} / \mathrm{cm}^{3}$ PSBF Encapsulation 

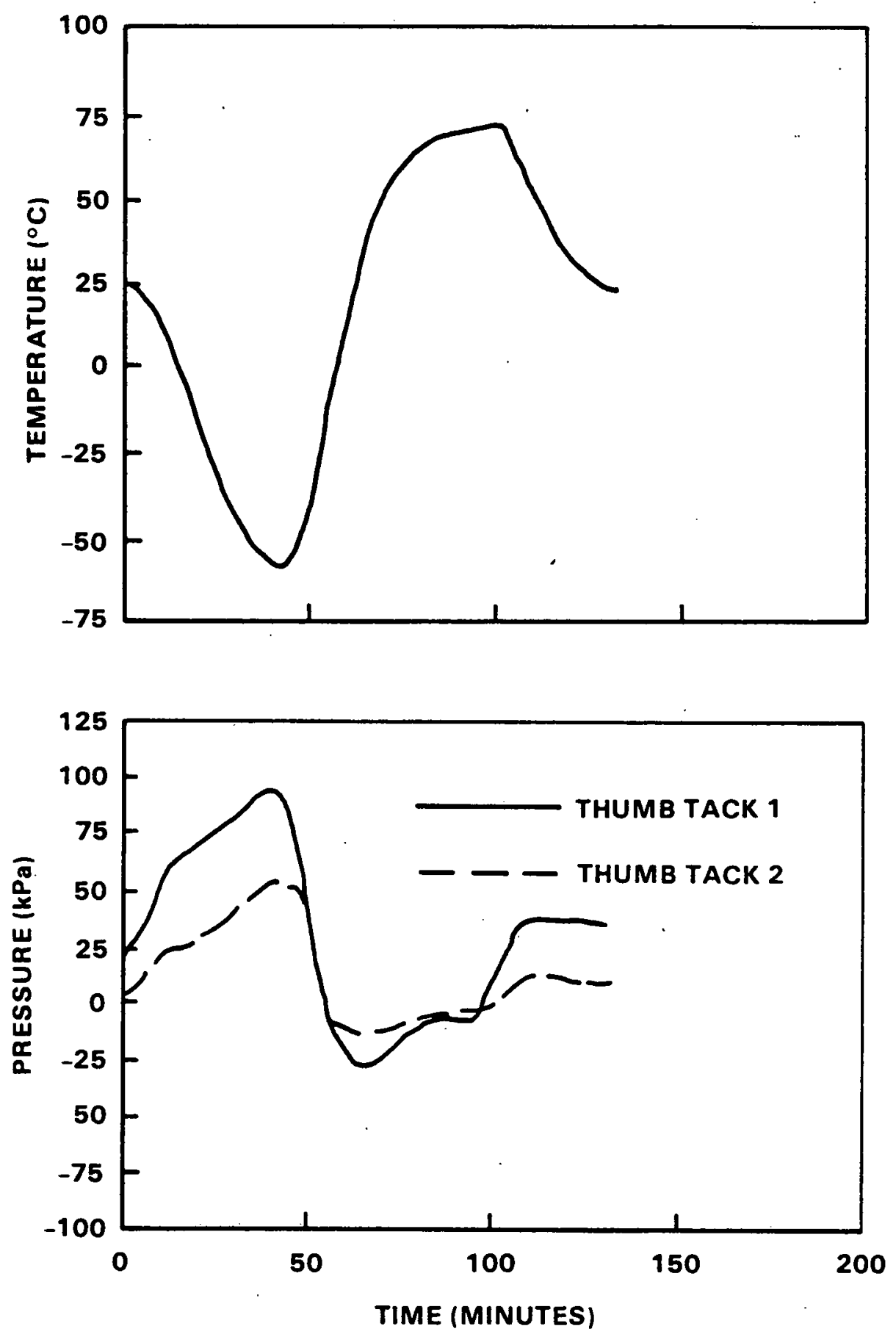

Figure 10. Pressures for First Thermal Cycle of $0.4 \mathrm{~g} / \mathrm{cm}^{3}$ PSBF Encapsulation 

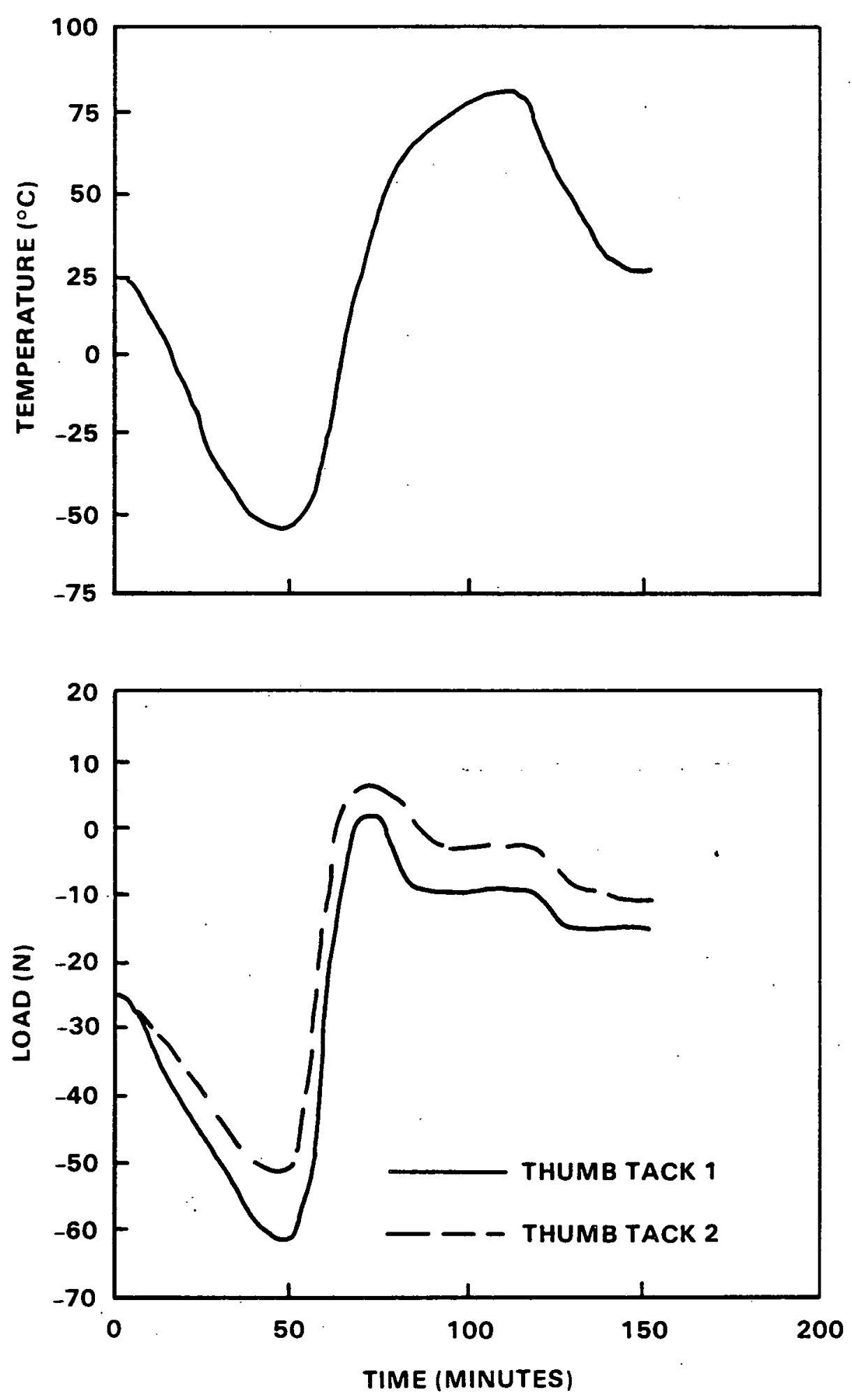

Figure 11. Loads for First Thermal Cycle of $0.5 \mathrm{~g} / \mathrm{cm}^{3}$ PSBF Encapsulation 

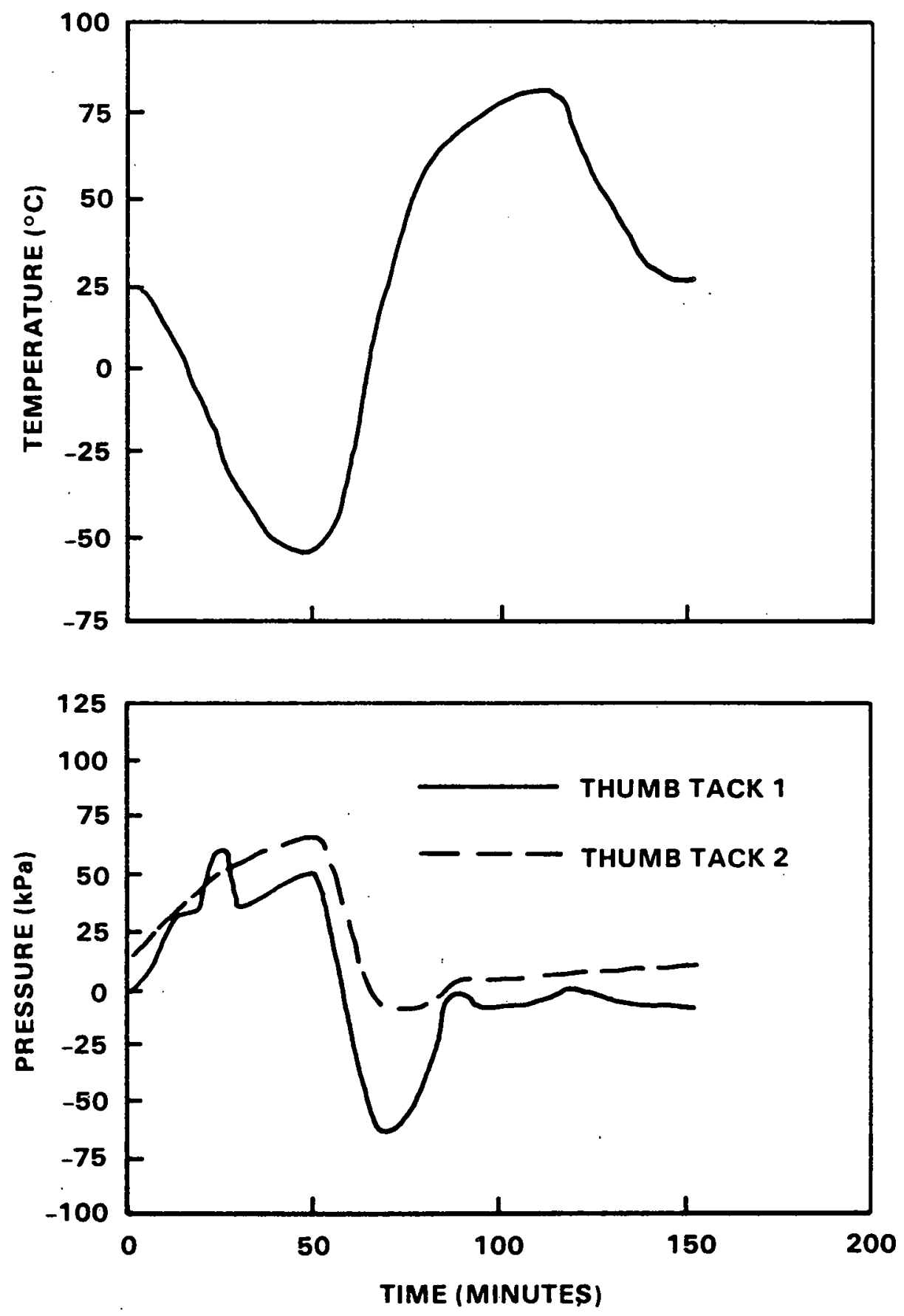

Figure 12. Pressures for First Thermal Cycle of $0.5 \mathrm{~g} / \mathrm{cm}^{3}$ PSBF Encapsulation 

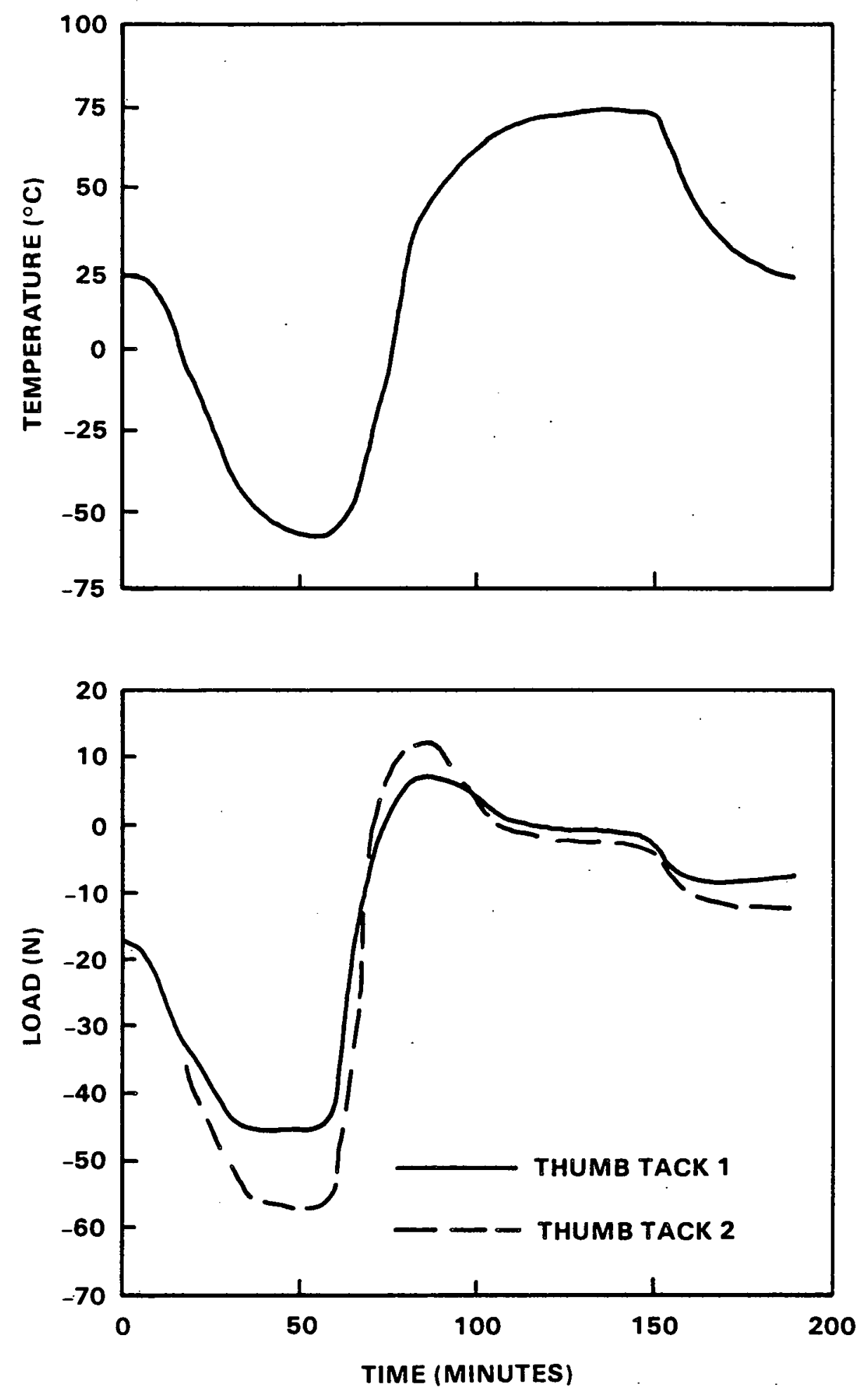

Figure 13. Loads for First Thermal Cycle of $0.6 \mathrm{~g} / \mathrm{cm}^{3}$ PSBF Encapsulation (3.6Percent Initial Pentane Content) 

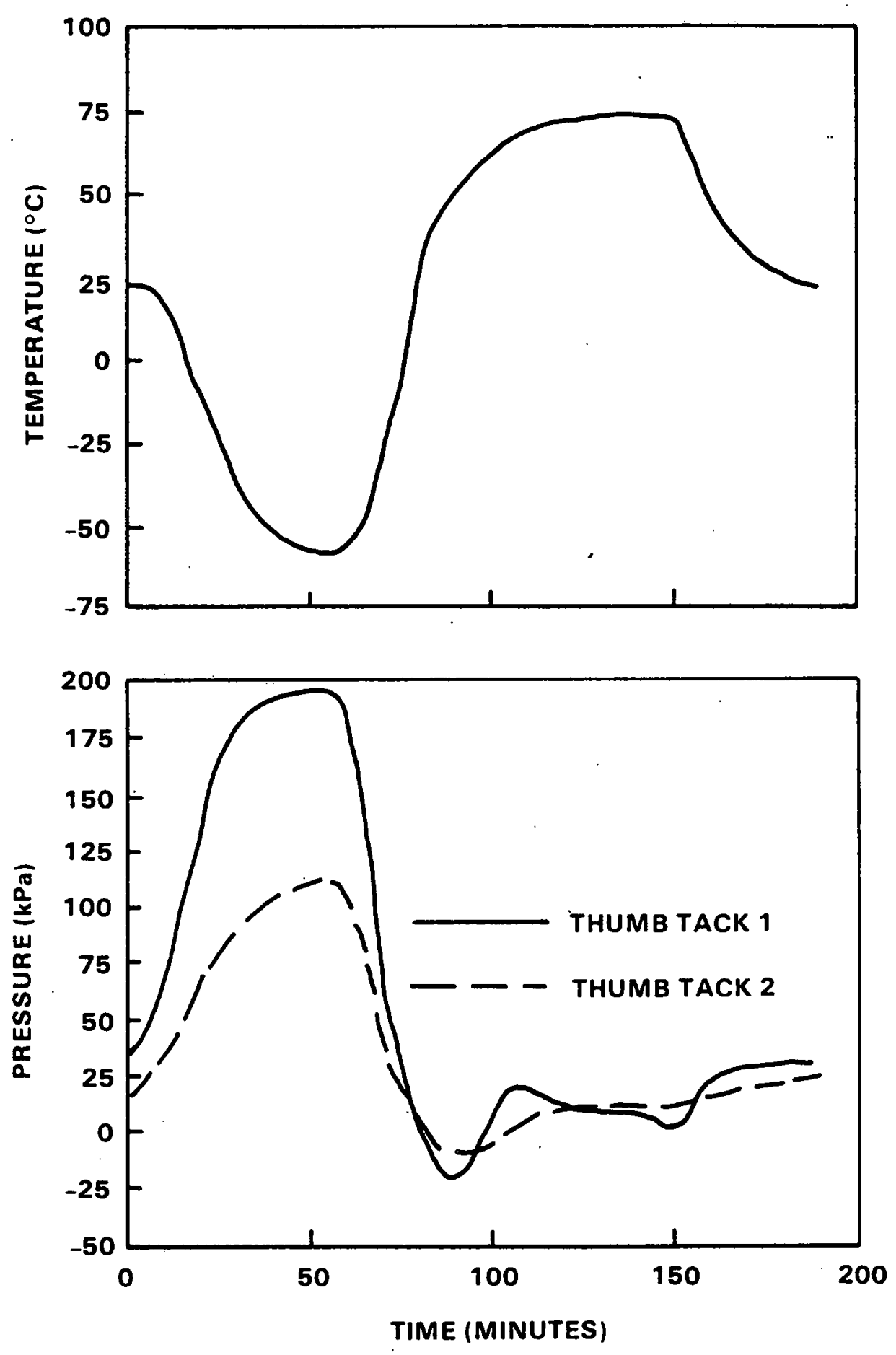

Figure 14. Pressures for First Thermal Cycle of $0.6 \mathrm{~g} / \mathrm{cm}^{3}$ PSBF Encapsulation (3.6Percent Initial Pentane Content) 

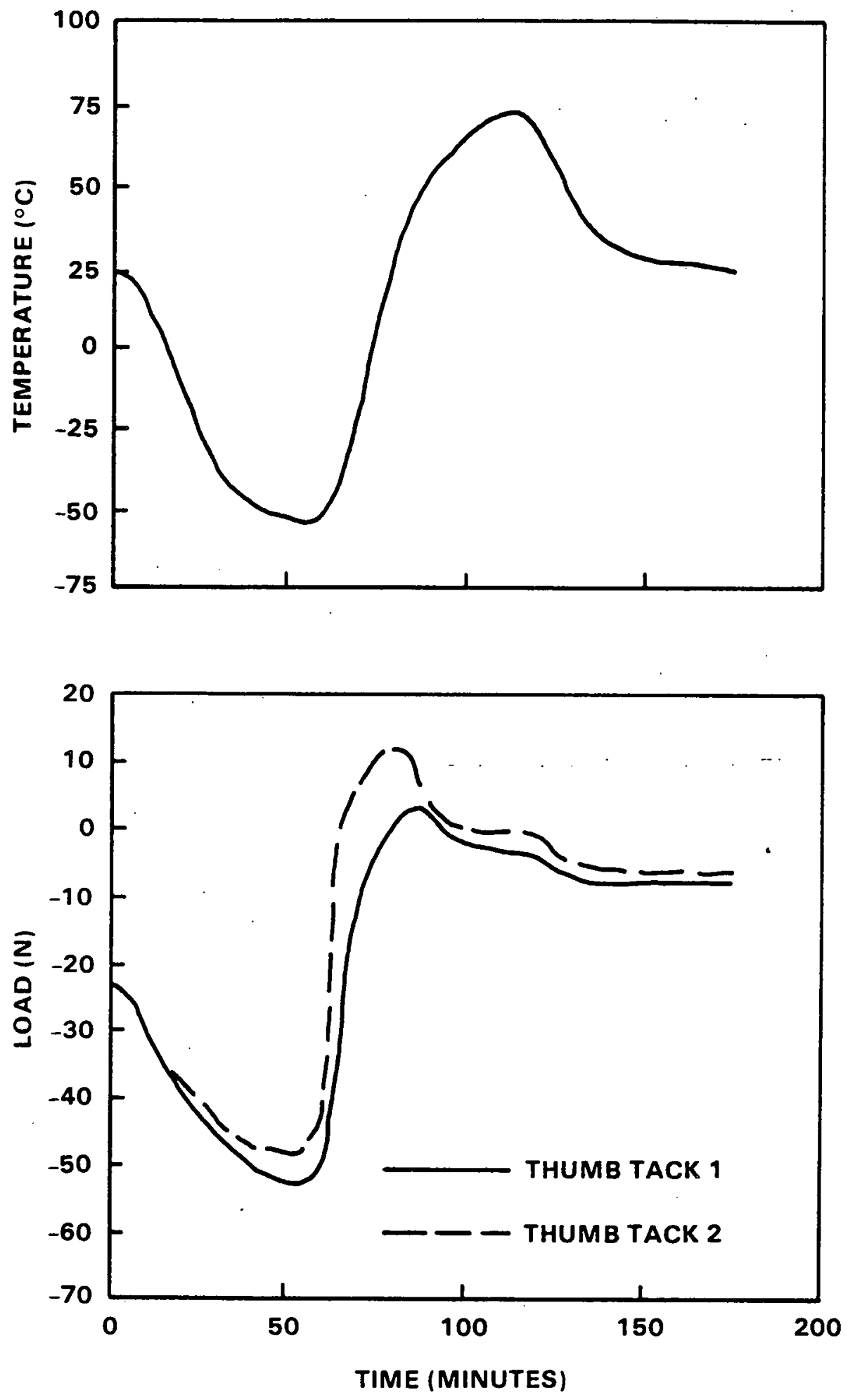

Figure 15. Loads for First Thermal Cycle of $0.6 \mathrm{~g} / \mathrm{cm}^{3}$ PSBF Encapsulation (6Percent Initial Pentane Content) 

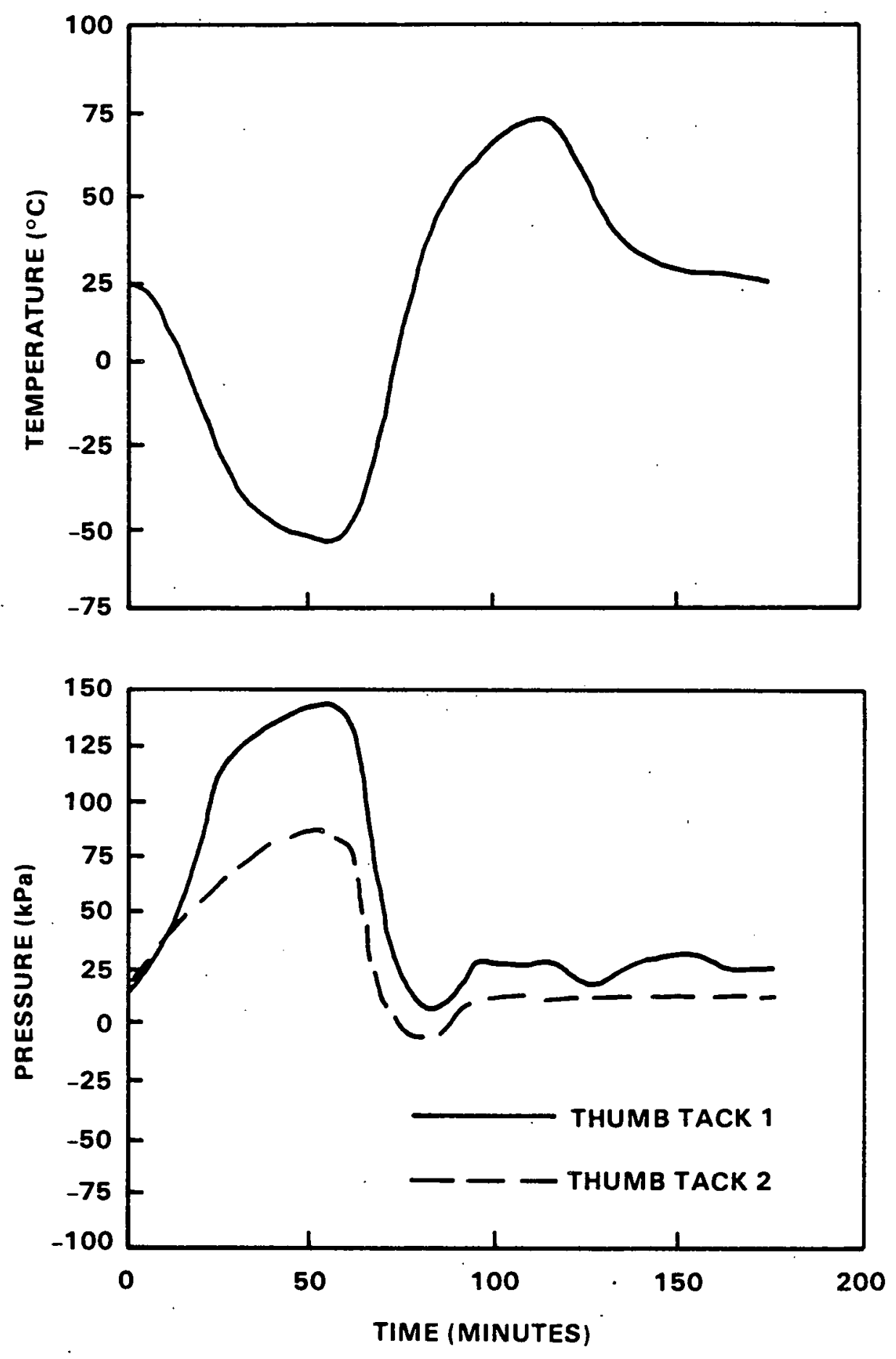

-

Figure 16. Pressures for First Thermal Cycle of $0.6 \mathrm{~g} / \mathrm{cm}^{3}$ PSBF Encapsulation (6Percent Initial Pentane Content) 
Any deflection measured should be directly related to a relaxation in force. No such relaxation was seen at $-54^{\circ} \mathrm{C}$; therefore, the small deflections recorded do not indicate movement in the solder joint. A movement of $0.051 \mathrm{~mm}$ at $-54{ }^{\circ} \mathrm{C}$ would completely relieve the force on the lead wire. A compressive load of $44.5 \mathrm{~N}$ would produce a stress of $89.6 \mathrm{MPa}$ in the copper lead wire of the thumb-tack, and a maximum shear stress of about $14 \mathrm{MPa}$ in the solder joint, a stress well below yield at $-54^{\circ} \mathrm{C}$. This again points to an adequate margin of safety for solder joints in units potted with 0.2 to $0.6 \mathrm{~g} / \mathrm{cm}^{3} \mathrm{PSBF}$.

Comparison of Results to Theoretical Predictions

The expected axial load on a thumb tack or the pressure on a transistor was estimated by a constrained thermal expansion calculation. ${ }^{3}, 4$ Using the known geometries, elastic moduli, and coefficients of thermal expansion, the load and pressure were calculated at $24^{\circ} \mathrm{C}$ after fusion. The load and pressure range for each thermal cycle also were calculated. A stressfree state was assumed at the PSBF fusion temperature. The resulting theoretical loads and pressure and their ranges are given in Table 3 .

Comparison between the theoretical loads of Table 3 and the measured loads of Tables 1 and 2 show good agreement. While the theoretical pressures of Table 3 were all much larger than measured values in Table 1 for cool down from the fusion temperature, the pressure range data of Table 2 show much better agreement. Two possible causes were that the thumb tack calculation required less severe idealization than the pressure transducer and that the pressure transducer was mounted near the PUF housing around the extensometer. The influence of that housing to lower the indicated pressure was not accounted for in the calculations.

Load, pressure, and deflection of electronic components caused by thermomechanical interaction with the encapsulating material are often desired for complex geometries. The finite element method (FEM) can easily handle such complications. To enhance the reliability of future calculations for more complex geometries, FEM studies are in progress for comparison with the thumb tack and pressure transducer experimental data and with the rough calculations presented here. The thumb tack FEM study also will show the actual stress distribution within the solder joint region.

Conclusions

Three conclusions can be drawn from this evaluation. 
Table 3. Calculated Loads and Pressure for PSBF

\begin{tabular}{llclll}
\hline & \begin{tabular}{l} 
At $24^{\circ} \mathrm{C}$ \\
\cline { 3 - 5 } $\begin{array}{l}\text { Density } \\
\left(\mathrm{g} / \mathrm{cm}^{3}\right)\end{array}$
\end{tabular} & $\begin{array}{l}\text { Load } \\
(\mathrm{N})\end{array}$ & $\begin{array}{l}\text { Pressure } \\
(\mathrm{kPa})\end{array}$ & $\begin{array}{l}\text { Load } \\
(\mathrm{N})\end{array}$ & $\begin{array}{l}\text { Pressure } \\
(\mathrm{kPa})\end{array}$ \\
\hline 0.2 & 11.1 & 29.6 & 19.1 & 50.3 \\
0.3 & 17.4 & 52.4 & 29.8 & 89.6 \\
0.4 & 21.8 & 75.1 & 37.4 & 128.2 \\
0.5 & 27.6 & 111.6 & 46.7 & 190.2 \\
0.6 & 27.6 & 115.1 & 47.1 & 195.0 \\
\hline
\end{tabular}

Loads and pressures do not change much for the PSBF density range from 0.4 to $0.6 \mathrm{~g} / \mathrm{cm}^{3}$. These are nearly equal encapsulants in terms of the thermomechanical load on solder joints and the pressure on electronic components:

No true movement of the lead in the solder joint was measured.

All the PSBF densities evaluated are mechanically safe for this thumb tack joint and for the specific transistor used as a pressure transducer. All densities were less severe encapsulants than $0.2 \mathrm{~g} / \mathrm{cm}^{3} \mathrm{PUF}$.

\section{ACCOMPLISHMENTS}

An experimental survey of encapsulation loads caused by $0.3,0.4$, 0.5 , and $0.6 \mathrm{~g} / \mathrm{cm}^{3}$ densities of PSBF has been made. These data are directly comparable to previously reported data for other encapsulant materials.

Loads calculated from constrained thermal expansion agreed well with experimental data. As a result, future calculations for other specific conditions may be used in lieu of more expensive direct experimentation.

\section{FUTURE WORK}

An instrumented dummy unit without electronic components installed will be used to measure PWB bending and other load/deflection conditions. An instrumented production equivalent unit will be used to measure direct loadings on the electronic components. 
Finite element stress analysis of the thumb tack and pressure transducer will give refined calculated results to compare with the experimental results obtained in this study. Finite element calculations then may be relied on for complex geometries where a hand calculation from constrained thermal expansion concepts is impossible. 
${ }^{1}$ D. C. Dyer and others, "Technique Completely Quantifies Stress in Encapsulated Component Lead Wires," Insulation/Circuits, Volume 23, Number 9, August, 1977, pp 38-40.

${ }^{2}$ D. J. Fossey, Evaluation of Polystyrene Bead Foam as an Encapsulant for Electronic Packages (Final Report). Bendix Kansas City: $\mathrm{BD} \overline{\mathrm{X}-613-2021}$ (Rev.), January, 1979 (Available from NTIS).

${ }^{3}$ G. D. Swanson, Design Manual for Potting Electronic Assemblies.

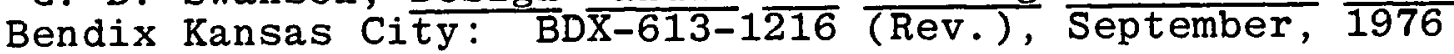
(Available from NTIS).

${ }^{4}$ E. Baker, "Calculation of Thermally Induced Mechanical Stresses in Encapsulated Assemblies," IEEE Transactions on Parts, Materials, and Packaging, Volume PMP-6, Number 4, December, $\overline{1970,}$ p $\overline{121-128}$. 
$B D X-613-2416$

THUMB TACK PHYSICAL MODEL EVALUATION OF POLYSTYRENE BEAD FOAM AS AN ENCAPSULANT FOR

ELECTRONIC PACKAGES, D. J. Fossey and G. D.

Swanson, Topical, March 1980.

A physical model in the shape of a thumb tack is used to measure forces on electronic component lead wires when soldered into printed wiring boards. Encapsulation of electronic packages in polystyrene bead foam of $0.2,0.3,0.4,0.5$, and $0.6 \mathrm{~g} / \mathrm{cm}^{3}$ densities was evaluated. No solder joint damage was seen. Crushing pressures on metal transistors also were safe for all

densities. Experimental data agreed well with

ELECTRONICS: Encapsulation

THUMB TACK PHYSICAL MODEL EVALUATION OF POLYSTYRENE BEAD FOAM AS AN ENCAPSULANT FOR

ELECTRONIC PACKAGES, D. J. Fossey and G. D.

Swanson, Topical, BDX-613-2416, March 1980.

A physical model in the shape of a thumb tack is 1 used to measure forces on electronic component I lead wires when soldered into printed wiring boards. Encapsulation of electronic packages in 1 polystyrene bead foam of $0.2,0.3,0.4,0.5$, and $0.6 \mathrm{~g} / \mathrm{cm}^{3}$ densities was evaluated. No solder joint damage was seen. Crushing pressures on metal transistors also were safe for all densities. Experimental data agreed well with

THUMB TACK PHYSICAL MODEL EVALUATION OF POLYSTYRENE BEAD FOAM AS AN ENCAPSULANT FOR ELECTRONIC PACKAGES, D. J. Fossey and G. D. Swanson, Topical, BDX-613-2416, March 1980.

A physical model in the shape of a thumb tack is used to measure forces on electronic component lead wires when soldered into printed wiring. boards. Encapsulation of electronic packages in polystyrene bead foam of $0.2,0.3,0.4,0.5$, and $0.6 \mathrm{~g} / \mathrm{cm}^{3}$ densities was evaluated. No solder joint damage was seen. Crushing pressures on metal transistors also were safe for all densities. Experimental data agreed well with 
theoretical calculations based on the concept of constrained thermal expansion.

theoretical calculations based on the concept of constrained thermal expansion.

theoretical calculations based on the concept of constrained thermal expansion. 